\title{
PENERAPAN MEDIA MACROMEDIA FLASH TERHADAP EFIKASI DIRI PADA MATA PELAJARAN TEKNOLOGI MENJAHIT DI KELAS X TATA BUSANA SMK NEGERI 2 SINGARAJA
}

\author{
Ni Made Oktasari, I Dewa Ayu Made Budhyani, Ni Ketut Widiartini \\ Program Studi Pendidikan Kesejahteraan Keluarga, Fakultas Teknik dan Kejuruan \\ Universitas Pendidikan Ganesha \\ Singaraja, Indonesia \\ e-mail : oktasari6601@gmail.com,ayu.budhyani@undiksha.ac.id, \\ ketut.widiartini@undiksha.ac.id
}

\begin{abstract}
Abstrak
Penelitian ini bertujuan untuk mendeskripsikan penerapan media pembelajaran macromedia flash terhadap efikasi diri siswa pada mata pelajaran teknologi menjahit di kelas X Tata Busana SMK Negeri 2 Singaraja. Penelitian ini dilakukan di SMK Negeri 2 Singaraja pada siswa kelas X Busana. Jenis penelitian Pre-Eksperimen dengan desain One Shot Case Study. Populasi dalam penelitian ini seluruh siswa kelas X Busana SMK Negeri 2 Singaraja tahun ajaran 2018/2019 yang berjumlah 31 siswa. Penentuan sampel dalam penelitian ini dilakukan dengan teknik sampel jenuh. Pengumpulan data dalam penelitian ini dilakukan dengan metode non tes yaitu menggunakan angket. Berdasarkan hasil perhitungan statistik deskriptif diperoleh hasil rerata skor efikasi diri siswa setelah diberi perlakuan yaitu 112,84. Berdasarkan hasil perhitungan dengan uji-t diperoleh $t_{\text {hitung }}$ sebesar 28,69 sedangkan $t_{\text {tabel }}$ dengan $\mathrm{dk}=(31-1)$ dengan taraf signifikan $5 \%$ adalah 1,69 . Hal ini berarti, $t_{\text {hitung }}$ lebih besar dari $t_{\text {tabel }}\left(\mathrm{t}_{\text {hitung }}>\mathrm{t}_{\text {tabel }}\right)$ sehingga $\mathrm{H}_{0}$ ditolak dan $\mathrm{H}_{1}$ diterima. Ini berarti terdapat peningkatan efikasi diri siswa pada mata pelajaran teknologi menjahit setelah penerapan media pembelajaran macromedia flash di kelas $\mathrm{x}$ tata busana SMK Negeri 2 Singaraja.
\end{abstract}

Kata kunci: efikasi diri, macromedia flash, teknologi menjahit

\begin{abstract}
Aim of this study is to describing the usage of macromedia flash learning media to students' self-efficacy on Sewing Technology subject in 10th grade students of Fashion Design in SMK 2 singaraja. This study is done at SMK Negeri 2 Singaraja among 10th grade Fashion Design students. Type of this study is pre-eksperimen and categorized as One Shot Case Study. Population in this sudy is all 31 students of 10th grade fashion design in SMK 2 Singaraja academic year 2018/2019. The method for choosing the sample uses sample jenuh technique. Method and technique of collecting the data for this study is non-test method. Based on the analysis with descriptive statistical calculations obtained the average scor of student's self-efficacy scores after being given treatment namely 112.84 . Based on the results of calculations with $\mathrm{t}$-test obtained $\mathrm{t}_{\text {count }}$ of 28.69 while $\mathrm{t}_{\text {table }}$ with $\mathrm{dk}=(31-1)$ with a significance level of $5 \%$ is 1.69 . This means, $t_{\text {count }}$ is greater than $t_{\text {table }}$ ( $t_{\text {count }}>t_{\text {table }}$ ) so that $H_{0}$ is rejected and $\mathrm{H}_{1}$ is accepted. This means that there is an increase in students' self-efficacy through the application of Macromedia Flash learning on Sewing Technology subject in 10th grade students of Fashion Design in SMK 2 singaraja.
\end{abstract}




\section{Keyword: self-efficacy, macromedia flash, sewing technology \\ PENDAHULUAN \\ dengan kemajuan ilmu pengetahuan dan teknologi.}

Pada saat ini, teknologi berkembang semakin pesat sehingga menuntut suatu negara untuk berkembang lebih maju. Perkembangan ilmu dan teknologi yang semakin pesat tersebut membuat semua orang mau tidak mau juga ikut melakukan perbaharuan disegala aspek termasuk pendidikan. Kemajuan suatu negara ditentukan oleh sumber daya manusia yang dihasilkan dan kualitas sumber daya yang baik ditentukan oleh pendidikan. Menurut Undang - undang Sisdiknas nomor 20 tahun 2003 Pendidikan adalah usaha sadar dan terencana untuk mewujudkan suasana belajar dan proses pembelajaran sedemikian rupa agar peserta didik dapat mengembangkan potensi dirinya secara aktif supaya memiliki pengendalian diri, kecerdasan, ketrampilan dalam bermasyarakat, kekuatan spiritual keagamaan, kepribadian serta akhlak yang mulia. Sehingga sebagai sebuah negara yang sedang berkembang, Indonesia sedang gencar-gencarnya meningkatkan mutu pendidikan yang ada guna meningkatkan pertumbuhan ekonomoni negara. Pendidikan merupakan pilar utama kemajuan suatu bangsa, oleh karena itu setiap warga negara memiliki hak yang sama untuk mengenyam pendidikan sehingga pemerintah selalu berusaha memperbaharui mutu pendidikan yang ada.

Salah satu tempat dimana proses pembelajaran berlangsung adalah sekolah, contohnya Sekolah Menengah Kejuruan (SMK) merupakan salah satu dari penyelenggara pendidikan. SMK sebagai salah satu lembaga pendidikan kejuruan memiliki tugas untuk mempersiapkan peserta didiknya untuk dapat bekerja pada bidang-bidang tertentu. Dalam proses pembelajarannya, SMK dilengkapi dengan ilmu pengetahuan secara teori dan membekali peserta didik melalui praktik sehingga dalam perkembangannya SMK dituntut harus mampu menciptakan Sumber Daya Manusia (SDM) yang dapat berakselerasi
Sekolah Menengah Kejuruan sebagai pencetak tenaga kerja yang siap pakai harus membekali peserta didiknya dengan pengetahuan dan keterampilan yang sesuai dengan kompetensi program keahlian mereka masing-masing agar siap bersaing di dalam dunia kerja, salah satu program keahlian tersebut adalah Tata Busana. Mata pelajaran teknologi menjahit merupakan salah satu mata pelajaran teori (kognitif) dan praktek (psikomotorik) yang ada di SMK Negeri 2 Singaraja. Dalam mata pelajaran teknologi menjahit, metode pembelajaran yang digunakan yaitu berupa ceramah. Kendala dalam proses pembelajaran ini adalah minimnya penggunaan media pembelajaran yang menyebabkan pemahaman akan materi produktif masih kurang dimengerti siswa. Metode ceramah menyebabkan siswa bersikap pasif dan hal ini dapat menimbulkan kebingungan bagi siswa. Selain itu, keterbatasan sarana dan prasarana seperti ruang kelas yang tidak sepadan dengan banyaknya jumlah siswa mempengaruhi proses pembelajaran baik teori maupun praktek yang dilaksanakan di kelas sehingga pembelajaran menjadi kurang kondusif dikarenakan banyak siswa yang mengobrol diluar topik materi atau pelajaran yang disampaikan guru. Keterbatasan jam pembelajaran juga menjadi kendala bagi guru dan siswa untuk mencapai tujuan pembelajaran. Jadi dapat disimpulkan bahwa permasalahan yang ada di SMK Negeri 2 Singaraja terkait mata pelajaran teknologi menjahit di kelas X Tata Busana adalah sebagai berikut:

1. Guru dalam proses pembelajaran masih menggunakan metode ceramah.

2. Minimnya penggunaan media pembelajaran pada proses pembelajaran.

3. Keterbatasan sarana dan prasarana tidak sebanding dengan banyaknya jumlah siswa dikelas sehingga 


\section{proses pembelajaran menjadi} kurang kondusif.

4. Pada saat praktek berlangsung siswa lebih banyak menunjukkan sikap pasif dengan cenderung menunggu perintah dari guru.

5. Keterbatasan jam pembelajaran menjadi kendala dalam mencapai tujuan pembelajaran.

Selain faktor eksternal, hambatan belajar juga bisa datang dari faktor internal yaitu karakter dan keadaan psikologis siswa. Karakteristik setiap siswa berbeda sehingga ada siswa yang mudah mengerti dan ada siswa yang perlu dijelaskan berulang kali untuk memahami suatu materi. Motivasi belajar, minat, bakat, sikap, kesehatan, kecerdasan dan keyakinan diri yang baik akan mampu mengarahkan siswa ke dalam kondisi belajar yang baik. Keyakinan diri inilah yang disebut dengan efikasi diri.

\section{Berdasarkan teori Bandura} (Ghufron, 2014 : 73) Efikasi diri adalah keyakinan individu mengenai kemampuan dirinya dalam melakukan tugas atau tindakan yang diperlukan untuk mencapai hasil tertentu. Efikasi diri dapat mempengaruhi siswa dalam memilih suatu tugas yang mana dikategorikan mudah dan sulit. Dibanding dengan siswa yang memiliki efikasi diri rendah, siswa dengan efikasi diri yang tinggi cenderung gigih, ulet serta merasa tertantang untuk mencoba hal-hal baru sehingga merasa bersemangat dalam menyelesaikan tugas. Dalam teori sosial kognitif (Bandura, 1997) rendahnya efikasi diri akan menyebabkan meningkat-nya kecemasan dan perilaku menghindar. Individu akan menghindari aktivitas-aktivitas yang dapat memperburuk keadaan, hal ini bukan disebabkan oleh ancaman tapi karena merasa tidak mempunyai kemampuan untuk mengelola aspek-aspek yang berisiko. Tinggi dan rendahnya efikasi diri yang dimiliki siswa akan memotivasi mereka secara kognitif untuk bertindak dan berusaha mencapai tujuan. Siswa dengan efikasi diri yang tinggi akan selalu berpikir positif, gigih berusaha dan menganggap kegagalan sebagai akibat dari kurangnya usaha, pengetahuan dan ketrampilan. Sedangkan siswa dengan efikasi diri yang rendah cenderung menganggap tugas sebagai ancaman, tidak mampu berpikir dan bersikap di bawah tekanan serta sulit memperbaiki diri ketika mengalami kegagalan.

Dari hasil observasi yang telah dilakukan peneliti di SMK Negeri 2 Singaraja, diperoleh data efikasi diri siswa sebagai berikut

Tabel 1. Data efikasi diri siswa SMK

\begin{tabular}{|l|l|l|l|}
\hline Kategori & Interval & Frekuensi & Persentase \\
\hline $\begin{array}{l}\text { Sangat } \\
\text { Tinggi }\end{array}$ & $\begin{array}{l}120- \\
150\end{array}$ & 2 & $6 \%$ \\
\hline Tinggi & $\begin{array}{l}100- \\
<120\end{array}$ & 8 & $26 \%$ \\
\hline Sedang & $\begin{array}{l}80- \\
<100\end{array}$ & 18 & $58 \%$ \\
\hline Rendah & $\begin{array}{l}60- \\
<80\end{array}$ & 3 & $10 \%$ \\
\hline $\begin{array}{l}\text { Sangat } \\
\text { Rendah }\end{array}$ & $\begin{array}{l}30-60 \\
<60\end{array}$ & $0 \%$ \\
\hline \multicolumn{2}{|c|}{ Jumlah } & 31 & $100 \%$ \\
\hline
\end{tabular}

Negeri 2 Singaraja

Berdasarkan data tersebut, diketahui terdapat 2 siswa sebanyak $6 \%$ yang memiliki efikasi diri dengan klasifikasi sangat tinggi, 8 siswa sebanyak $26 \%$ yang memiliki efikasi diri tinggi, 18 siswa sebanyak $58 \%$ yang memiliki efikasi diri sedang, 3 siswa sebanyak $10 \%$ yang memiliki efikasi diri rendah, dan tidak terdapat siswa yang memiliki efikasi diri sangat rendah. Selain itu, nilai rerata yang diperoleh dari keseluruhan nilai siswa adalah 93,3 sehingga dikategorikan sedang.

Salah satu solusi untuk meningkatkan efikasi diri siswa adalah denganmenerapkan media pembelajaran yang tepat. Media pembelajaran merupakan salah satu sarana komunikasi yang dapat membantu proses pembelajaran di kelas. Hamalik dalam (Azhar Arsyad, 2002:15) menjelaskan bahwa penggunaan media pembelajaran dalam proses belajar mengajar dapat 
membangkitkan keinginan dan minat yang baru, membangkitkan motivasi dan rangsangan kegiatan belajar, dan bahkan membawa pengaruh-pengaruh psikologis siswa. Selain itu melalui media pembelajaran yang tepat dapat memudahkan siswa dalam mengikuti proses pembelajaran dan membantu guru berkomunikasi dengan siswa sehingga guru tidak kehabisan tenaga dan waktu serta siswa dapat lebih mudah memahami materi yang diajarkan. media pembelajaran macromedia flash merupakan salah satu pemanfaatan IPTEK di dalam dunia pendidikan. Dengan penggunaan media pembelajaran macromedia flash berbasis audio visual dapat membantu guru dalam menjelaskan atau menggambarkan proses dan tahapan yang terjadi pada suatu media asli yang sulit dimengerti atau dijelaskan ke siswa sehingga dengan penggunaan media pembelajaran macromedia flash berbasis audio visual siswa dapat lebih mudah mengerti dan menangkap suatu materi yang diharapkan dapat meningkatkan efikasi diri siswa.

Sesuai dengan tujuan tersebut guna meningkatkan efikasi diri siswa pada mata pelajaran teknologi menjahit di kelas $X$ Tata Busana SMK Negeri 2 Singaraja adalah dengan memperbaharui proses pembelajaran melalui variasi media pembelajaran yang tepat, mengingat karakteristik siswa pada SMK Negeri 2 Singaraja berbeda-beda. Maka dari itu perlu dilakukan penelitian untuk menentukan media pembelajaran yang tepat untuk mengetahui seberapa tinggi efikasi diri siswa dan penelitian ini dilakukan untuk meneliti apakah penerapan media pembelajaran macromedia flash efektif untuk meningkatkan efikasi diri yang dimiliki siswa.

Menurut Bandura (dalam Jess Feist \& Feist, 2010:2012) dikutip dari Kurniawati, https://eprints.uny.ac.id/36954/ "efikasi Diri adalah keyakinan seseorang dalam kemampuannya untuk melakukan suatu bentuk kontrol terhadap fungsi orang itu sendiri dan kejadian dalam lingkungan". Bandura juga menggambarkan Efikasi Diri sebagai penentu bagaimana orang merasa, berfikir, memotivasi diri, dan berperilaku.

Efikasi diri adalah penilaian diri, apakah dapat melakukan tindakan yang baik atau salah, bisa atau tidak bisa mengerjakan sesuai dengan yang diisyaratkan. Efikasi diri ini berbeda dengan aspirasi(cita-cita). Karena cita-cita menggambarkan sesuatu yang ideal yang seharusnya dapat dicapai, sedang efikasi menggambarkan penilaian kemampuan diri. Selain itu, Baron dan Byrne (dalam Ghufron, 2011:73) mendefenisikan efikasi diri sebagai evaluasi seseorang mengenai kemampuan atau kompetensi dirinya untuk melakukan suatu tugas, mencapai tujuan, dan mengatasi hambatan. Bandura dan Woods (dalam Ghufron, 2011:74) menjelaskan bahwa efikasi diri mengacu pada keyakinan akan kemampuan individu untuk menggerakkan motivasi, kemampuan kognitif, dan tindakan yang diperlukan untuk memenuhi tuntutan situasi.

Menurut Bandura (dalam Ghufron, 2010:88), efikasi diri pada diri tiap individu akan berbeda antara satu individu dengan yang lainnya berdasarkan tiga dimensi. Berikut adalah tiga dimensi tersebut, yaitu:

1. Tingkat (level) Dimensi ini berkaitan dengan derajat kesulitan tugas ketika individu merasa mampu untuk melakukannya.

2. Kekuatan (strength) Dimensi ini berkaitan dengan tingkat kekuatan dari keyakinan atau pengharapan individu mengenai kemampuannya.

3. Generalisasi (geneality) Dimensi ini berkaitan dengan luas bidang tingkah laku yang mana individu merasa yakin akan kemampuannya

Menurut Ibrahim dkk. (dalam Wawan Sudatha \& I Made Tegeh, 2015:05), media pembelajaran adalah segala sesuatu yang dapat digunakan untuk menyalurkan pesan (bahan pembelajaran) sehingga dapat merangsang perhatian, minat, pikiran dan perasaan pembelajar (siswa) dalam kegiatan belajar untuk mencapai tujuan 
pembelajaran tertentu contohnya gambar, bagan, model, film, video, computer, dan sebagainya. Pendapat tersebut sejalan dengan pendapat dari Miarso (dalam Wawan Sudatha \& I Made Tegeh, 2015:06) mengemukakan bahwa media belajar adalah segala sesuatu yang dapat digunakan untuk merangsang pikiran, perasaan, perhatian, dan kemauan siswa sehingga dapat mendorong terjadinya proses belajar pada diri siswa.

Sadiman, dkk. (dalam Wawan Sudatha \& I Made Tegeh, 2015:06) mengemukakan fungsi serta kegunaan media pendidikan sebagai berikut:

1) memperjelas penyajian pesan agar tidak terlalu bersifat verbalistis.

2) Mengatasi keterbatasan ruang, waktu dan daya indera, seperti: obyek terlalu besar, obyek yang kecil, gerak yang terlalu lambat atau terlalu cepat, kejadian di masa lampau, obyek yang terlalu kompleks, dan konsep yang terlalu luas.

3) Mengatasi sikap pasif peserta didik, dalam hal ini menimbulkan gairah belajar, interaksi yang lebih langsung antara anak didik dengan lingkungan dan kenyataan, kemungkinan anak didik belajar sendiri - sendiri.

4) Memberikan perangsang yang sama, mempersamakan pengalaman, dan menimbulkan persepsi yang sama.

Menurut Setyosari dan Sikhabuden (dalam Wawan Sudatha \& I Made Tegeh, 2015:15) media diklasifikasi menjadi tiga kelas, yakni media audio, media visual, dan media audio visual.

1) Media audio adalah media yang hanya mengandalkan suara saja, seperti radio, cassete tape recorder, dan piringan hitam. Media ini tidak cocok untuk orang tuli atau mempunyai kelainan dalam pendengaran.

2) Media visual adalah media yang hanya mengandalkan indera penglihatan. Media visual ini ada yang menampilkan gambar diam seperti film strip (film rangkai), foto, gambar atau lukisan, cetakan, dan ada pula yang menampilkan gambar atau symbol yang bergerak seperti film bisu dan film kartun.
3) Media audio visual adalah media yang mempunyai unsur suara dan unsur gambar. Jenis media ini mempunyai kemampuan yang lebih baik, karena meliputi kedua jenis media yang pertama dan kedua. Media ini dibagi ke dalam audio visual diam (slide bersuara, film rangkai bersuara dan cetak suara) dan audio visual gerak (film suara, video cassete, aplikasi flash salah satunya macromedia flash).

Menurut Dhani Yudhiantoro (2006 : 01) Macromedia flash adalah sebuah program yang ditujukan kepada para desainer maupun programmer yang bermaksud merancang animasi untuk pembuatan halaman web, presentasi untuk tujuan bisnis maupun proses pembelajaran hingga pembuatan game interaktif serta tujuan-tujuan lain yang lebih spesifik. Macromedia flash merupakan gabungan konsep pembelajaran dengan teknologi audio visual yang mampu menghasilkan fiturfitur baru yang dapat dimanfaatkan dalam pendidikan. Pembelajaran berbasis multimedia tentu dapat menyajikan materi pelajaran yang lebih menarik , tidak monoton dan memudahkan penyampaian. Mata pelajaran teknologi menjahit merupakan salah satu mata pelajaran yang harus ditempuh siswa kelas $X$ Tata Busana di SMK Negeri 2 Singaraja. Mata pelajaran teknologi menjahit adalah mata pelajaran teori sekaligus praktek yang mengajarkan peserta didik untuk mengenal alat-alat menjahit serta mempelajari langkah-langkah awal menjahit.

\section{METODE}

Penelitian ini dilakukan di SMK Negeri 2 Singaraja, pada rentang waktu semester II (Genap) tahun ajaran 2018/2019 tepatnya dari bulan april 2019 sampai dengan mei 2019. Penelitian ini merupakan jenis penelitian PreExperiment. Pada penelitian ini menggunakan model Sugiyono karena penelitian ini lebih mudah dibanding 
model eksperimen lain. Bentuk desain penelitian eksperimen yang akan digunakan yaitu One Shot Case Study.

Gambar 1. desain penelitian one shot case study

$\mathrm{X} \quad=$ penerapan media pembelajaran Macromedia Flash

$\mathrm{O}=$ = Pemberian kuisioner efikasi diri

Pengambilan sampel penelitian ini dilakukan dengan teknik nonprobability sampling yaitu sampling jenuh. Menurut Sugiyono (2017: 85) sampling jenuh adalah teknik penentuan sampel bila semua anggota populasi digunakan sebagai sampel. Dalam penenilitian ini yang menjadi sampel adalah seluruh siswa kelas X Tata Busana di SMK Negeri 2 Singaraja. Metode pengumpulan data yang digunakan dalam penelitian ini adalah: teknik pengamatan atau observasi dan angket (kuisioner).

\section{HASIL PENELITIAN}

Penerapan media pembelajaran macromedia flash pada mata pelajaran teknologi menjahit di kelas X Tata Busana dilaksanakan dengan delapan kali pertemuan. Terlebih dahulu, siswa memperhatikan materi yang akan dipelajari sesuai dengan silabus dan RPP teknologi menjahit kelas X Tata Busana yaitu materi saku yang ditampilkan pada media pembelajaran macromedia flash, memahami bermacam-macam jenis saku. Kemudian guru menunjukkan fragmen macam-macam saku pada siswa sehingga siswa dapat melihat secara nyata macam-macam saku yang akan dipraktikkan. Masing-masing siswa mulai menyiapkan mesin dan alat jahitnya, guru membagikan potongan-potongan kain yang sudah disiapkan untuk praktik kepada masing-masing siswa kemudian menjelaskan langkah demi langkah dengan bantuan video yang ditayangkan pada media pembelajaran macromedia flash. Selanjutnya siswa mulai mempraktikan langkah demi langkah yang ditayangkan dalam video dengan pengawasan dari guru. Media pembelajaran macromedia flash membantu guru dalam memvisualisasikan proses pembelajaran sehingga memudahkan siswa dalam menangkap

\section{$\mathrm{XO}$}

materi yang dimaksud, membantu penyebaran informasi secara merata, serta meningkatkan sikap dan perhatian siswa yang memberi pengaruh pada psikologis siswa yaitu motivasi, semangat dan efikasi diri siswa dalam belajar.

Penerapan media pembelajaran macromedia flash pada mata pelajaran teknologi menjahit di kelas X Tata Busana dilaksanakan dalam kurun waktu 8 (delapan) kali pertemuan, setelah itu siswa dibagikan angket efikasi diri yang disusun dengan tiga indikator yaitu level/magnitude(kesulitan tugas), strength (kekuatan atau keyakinan kemampuan individu), dan generality (luas bidang tingkah laku). Selanjutnya angket efikasi diri dikumpulkan kembali dan dicari skornya untuk dimasukkan ke skala interval untuk mengetahui peningkatan efikasi diri siswa.

Penggunaan media pembelajaran audio visual atau video yang ditayangkan pada media pembelajaran macromedia flash dapat menarik perhatian siswa dan minat siswa dalam mengikuti pelajaran. Pendapat tersebut didukung oleh Ibrahim dkk. (dalam Wawan Sudatha\&I Made Tegeh, 2015: 05) menyatakan bahwa "Media pembelajaran adalah segala sesuatu yang dapat digunakan untuk menyalurkan pesan (bahan pembelajaran) sehingga dapat merangsang perhatian, minat, pikiran dan perasaan siswa dalam kegiatan belajar untuk mencapai tujuan pembelajaran". selain itu, Bandura (1995) menyatakan salah satu karakteristik dari individu yang memiliki efikasi diri yang tinggi adalah memiliki minat dan ketertarikan untuk terlibat dalam aktivitas. Ketertarikan dan minat siswa dapat dilihat dari aktifnya siswa bertanya mengenai materi pelajaran serta respon siswa terhadap media yang diterapkan. Penerapan media pembelajaran macromedia flash mendapat antusias dari siswa, terdapat 18 siswa (58\%) memberi 
respon yang sangat baik dan sebanyak 13 siswa (42\%) memberikan respon yang baik terhadap penerapan media pembelajaran macromedia flash. $\mathrm{Hal}$ tersebut didukung oleh penelitian yang dilakukan Togig Hidayat dan Aisyah Endah Palupi dimana hasil penelitian menunjukkan bahwa penerapan media pembelajaran berbasis Macromedia Flash mampu meningkatkan respon siswa serta hasil belajar siswa.

\section{Media pembelajaran Macromedia} Flash berbasis audio visual dapat meningkatkan efikasi diri siswa. Melalui penerapan media pembelajaran macromedia flash berbasis audio visual, rasa penasaran siswa terhadap proses pembelajaran akan terisi sehingga dapat memacu motivasi siswa yang kemudian mempengaruhi keyakinan siswa itu sendiri dalam melaksanakan pembelajaran. Pendapat ini didukung oleh Bandura (dalam Jess feist \& feist, 2015: 213-215) yang menyatakan bahwa "Efikasi diri seseorang dapat dipengaruhi salah satunya oleh faktor persuasi sosial yaitu berdasarkan arahan, saran, bimbingan, serta individu yang diyakinkan secara verbal cenderung akan berusaha keras untuk mencapai keberhasilan serta faktor kondisi fisik dan emosional dimana individu yang mengalami semangat yang tinggi, aktif dan dalam kondisi emosi yang stabil akan membantu performa peserta didik dalam mengikuti proses pembelajaran". Selain itu, penerapan media pembelajaran juga dapat mendorong kemauan siswa dalam proses pembelajaran sehingga berpengaruh terhadap keyakinan atau efikasi diri siswa itu sendiri. Hal ini didukung oleh pendapat dari Miarso (dalam Wawan Sudatha \& I Made Tegeh, 2015: 06) bahwa "media belajar adalah segala sesuatu yang dapat digunakan untuk merangsang pikiran, perasaan, perhatian, dan kemauan siswa sehingga dapat mendorong terjadinya proses belajar dari diri siswa". Melalui media pembelajaran siswa dapat mengenali ketrampilan yang dimiliki oleh dirinya sendiri selain itu juga dapat meningkatkan pengetahuan siswa serta melatih kemampuan siswa dalam menganalisis langkah-langkah menjahit dalam media yang diterapkan. Hal ini didukung oleh penelitian yang dilakukan oleh Kudyawinanto dimana hasil penelitian menunjukkan bahwa layanan bimbingan konseling dengan media film efektif dalam meningkatkan efikasi diri siswa, hal ini karena penggunaan media film dapat membantu siswa mengenali ketrampilan yang dimilikinya, keahlian dan pengetahuan serta menghargai dirinya sendiri dalam menyelesaikan tugas-tugas perkembangan.

Sehingga dapat dikatakan bahwa terdapat peningkatan efikasi diri siswa melalui penerapan media pembelajaran Macromedia Flash pada siswa kelas $\mathrm{X}$ Busana SMK Negeri 2 Singaraja.

\section{SIMPULAN}

telah dilakukan adalah terdapat peningkatan efikasi diri siswa melalui penerapan media pembelajaran macromedia flash pada mata pelajaran teknologi menjahit di kelas X Tata Busana SMK Negeri 2 Singaraja. Hal ini ditunjukkan dengan adanya peningkatan rata-rata yang dilakukan pada saat observasi yaitu 93,03 meningkat menjadi 112,84 setelah diberi perlakuan, selain itu juga ditunjukkan dengan uji-t yakni pada taraf signifikan $5 \%$ diperoleh $t_{\text {hitung }}$ sebesar 28,69 sedangkan $t_{\text {tabel }}$ dengan $\mathrm{dk}=(31-1)$ dengan taraf signifikan 5\% adalah 1,69. Hal ini berarti, $t_{\text {hitung }}$ lebih besar dari $t_{\text {tabel }}$ ( $t_{\text {hitung }}>t_{\text {tabel }}$ ) sehingga $\mathrm{H}_{0}$ ditolak dan $\mathrm{H}_{1}$ diterima. Dengan demikian dapat disimpulkan bahwa terdapat peningkatan efikasi diri siswa melalui penerapan media pembelajaran macromedia flash pada mata pelajaran teknologi menjahit.

\section{SARAN}

Adapun saran yang dapat disampaikan berdasarkan penelitian yang telah dilakukan adalah sebagai berikut.

a. Bagi siswa

Dengan adanya penelitian ini, diharapkan kedepannya siswa dapat lebih bersikap aktif guna menciptakan kelas 
yang kondusif dalam proses pembelajaran.

b. Bagi guru

Dengan adanya penelitian ini, diharapkan guru dapat lebih terampil dalam merancang media pembelajaran guna memudahkan siswa dalam memahami proses pembelajaran.

c. Bagi sekolah

Dengan diadakannya penelitian ini, diharapkan media pembelajaran macromedia flash dapat dimanfaatkan sebaik mungkin sebagai salah satu media yang dapat membantu proses pembelajaran siswa, serta sekolah diharapkan memberi perhatian pada fasilitas belajar siswa agar siswa dapat belajar dengan nyaman di kelas.

\section{DAFTAR RUJUKAN}

Alwisol. 2009. Psikologi Kepribadian edisi revisi. Malang: UMM press.

Arsyad, Azhar. 2002. Media Pembelajaran. Jakarta: Raja Grafindo Persada.

Arikunto, Suharsimi Prof. Dr. 2006. Prosedur Penelitian Suatu Pendekatan Praktik cetakan ketigabelas. Jakarta:Rineka Cipta.

Bandura, A. 2006. Guide for Constructing Self-Efficacy Scales. New York. Tersedia pada https://www.uky.edu/ eushe2/Bandu ra/BanduraGuide2006 .pdf (diakses pada 23 mei 2018)

Bandura, A. 1995. self efficacy in chaging Societies. New York:Cambridge University press. Tersedia pada https://www.researchgate.net/profile/ Barr

yZimmerman/publication/247480203

Self-

efficacyandeducationaldevelopm ent/links/549b67770cf2b80371371a d5/Self-efficacy-andeducationaldevelo pmen t.pdf (diakses pada 23 mei 2018)

Bandura, A. 1994. Self-efficacy. In V. S. Ramachaudran (Ed.), Encyclopedia of human behavior (Vol. 4, pp. 7181). New York: Academic Press. (Reprinted in H. Friedman [Ed.], Encyclopedia of mental health.San Diego: Academic Press, 1998). Tersedia pada https://www.uky.edu/ eushe2/Bandu ra/Bandura 1994EHB. Pdf (diakses pada 20 mei 2018)

Dantes, Prof. Dr. Nyoman. 2012. Metode Penelitian. Yogyakarta: Andi.

Dantes, Prof. Dr. Nyoman. 2017. Desain Eksperimen dan Analisis Data. Depok: Rajawali Pers.

Depdiknas. 2003. Undang-undang RI No.20 tahun 2003. Tentang Sistem Pendidikan Nasional.

Ghufron, M. Nur \& Rini Risnawita S. 2010. Teori - Teori Psikologi. Jogjakarta: AR-RUZZ Media.

Kudyawinanto, Egan. 2016. "Pengaruh Layanan Bimbingan Kelompok dengan Media Film Terhadap Efikasi Diri Pada Siswa Kelas VII SMP Negeri 17 Surakarta Tahun Pelajaran 2015/2016". Universitas Slamet Riyadi. Volume 2, Nomor 2. Tersedia pada http://jurnalmahasiswa.unisri.ac.id/index.php/fki pbk/article/view/376 (diakses tanggal 13 juni 2019)

Kurniawati, Devi. 2016. "Hubungan antara efikasi diri dengan kemandirian belajar siswa kelas V SD Negeri SeKecamatan Srandakan". Universitas Negeri Yogyakarta. Volume 5, Nomor 24. Tersedia pada https://eprints.uny.ac.id/36954/ (diakses tanggal 20 mei 2018)

Kustandi, Cecep dan Bambang Sutjipto. 2013. Media Pembelajaran. Bogor:Ghalia Indonesia.

Madcoms. 2007. Mahir Dalam 7 Hari Macromedia Flash Pro 8. Yogyakarta:Andi Offset.

Purnama, Pupung Budi. 2004. Macromedia Flash dengan Swift 3D. Jakarta:Elex Media Komputindo. 
Jurnal Bosaparis: Pendidikan Kesejahteraan Keluarga

Volume 10, Nomor 1, Maret 2019

Subandi, Ahmad. 1982. Psikologi Sosial. Jakarta: Bulan Bintang.

Sudatha, I Gede Wawan dan Dr. I Made Tegeh. 2015. Desain Multimedia Pembelajaran. Yogyakarta:Media Akademi.

Sugiyono. 2017. Metode Penelitian Pendidikan: Pendekatan kuantitatif, kualitatif, dan R\&D. Bandung:Alfabeta.

Yudhiantoro, Dhani. 2006. Membuat Animasi Web dengan Macromedia Flash Professional 8. Yogyakarta:Andi Offset. 